\title{
Inhaltsübersicht.")
}

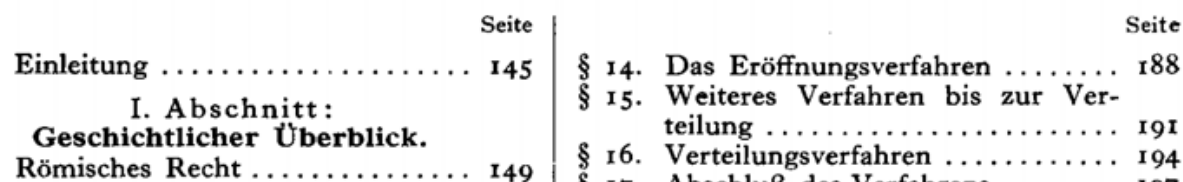

§ I. Römisches Recht ............ 149

\$ 2. Mittelalterlich-italienisches Recht . 150

§ 3. Alteres Deutsches Recht......... 150

\$ 4. Der gemeinrechtliche Konkurs .... I5 I

§ 5. Partikularrechtliche Reformgesetze ${ }_{152}$ II. Abschnitt : Konkursrecht.

§ 6. Die Konku1seröffnung . ......... 153

§ 7. Die Konkursmasse ........... 155

§ 8. Die Konkursforderungen......... 162

$\S$ 9. Schurebende Rechtsgeschäfte und Prozesse .................. I66

§ ı. Anfechtung von Rechtshandlungen des Gemeinschuldners ........ 173

$\S$ Ir. Beendigung des Konkurses ...... 178 III. Abschnitt:

Konkursverfahren.

$\S$ 12. Die Konkursorgane ........... 181

$\S$ 13. Das Konkursverfahren im allgemeinen ................ 186

§ 17. Abschluß des Verfahrens ........ 197

IV. Abschnitt :

\section{Besondere Konkursarten.}

$\S$ I8. Konkurs einer Aktiengesellschaft usw. ..................... 200

$\S 19$. Konkurs einer offenen Handelsgesellschaft usw. .......... 201

$\S 20$. Konkurs einer eingetragenen $\mathrm{Ge}-$ nossenschaft usw. ........... 202

$\S$ 21. Nachlaßkonkurs usw. .......... 204

$\S 22$. Inlands- und Auslandskonkurs ... 205

V. Abschnitt :

\section{Vergleich zur Abwendung} des Konkurses.

§ 23. Allgemeines ................ 205

$\S$ 24. Grundzüge $\ldots \ldots \ldots \ldots \ldots \ldots \ldots, 206$

1) Die nachfolgende Darstellung beschränkt sich auf das Allerwichtigste des Konkur rechts, sie umfaßt daher nur die Grundzüge dieses Rechtsgebiets. 
